\title{
Sprawozdanie z prac w Studium Polski Podziemnej w Londynie w 2016 r.
}

W dniach 28 sierpnia - 30 września 2016 r. miał miejsce mój pobyt w Studium Polski Podziemnej w Londynie, który zorganizowany został przez Naczelną Dyrekcję Archiwów Państwowych w ramach programu wspierania instytucji polonijnych. W tym czasie pracowałam w Studium jako członek czteroosobowego zespołu, złożonego z archiwistów reprezentujących różne archiwa państwowe w Polsce (Archiwum Akt Nowych, Archiwum Państwowe w Warszawie, Archiwum Państwowe w Szczecinie).

Studium Polski Podziemnej zostało powołane do życia w 1947 r. przez znanych działaczy Polskiego Podziemia, m.in. Tadeusza Bora-Komorowskiego, Kazimierza Iranka-Osmeckiego, Antoniego Montera-Chruściela, Andrzeja Pomiana, Tadeusza Żenczykowskiego, Tadeusza Pełczyńskiego. Jest instytucją archiwalną i naukową, gromadzącą materiały archiwalne z okresu II wojny światowej, związane zwłaszcza z Polskim Państwem Podziemnym. Najcenniejszą część zasobu stanowią akta Oddziału VI Sztabu Naczelnego Wodza w Londynie oraz Działu Społecznego Ministerstwa Spraw Wewnętrznych Rządu Polskiego na Uchodźstwie.

Na co dzień Studium przeprowadza kwerendy w zasobie i digitalizuje zbiory oraz prowadzi pracownię naukową, w której udostępnia akta, w dużej mierze opierając swoje działania na pracy wolontariuszy. W ewidencjonowaniu, porządkowaniu i opracowaniu akt profesjonalnie wspomagają je archiwiści z polskich instytucji, m.in. z archiwów państwowych. Studium skupia także wokół siebie wielopokoleniowe środowisko Polaków żyjących na emigracji.

Zadaniem zespołu, którego byłam członkiem, było uporządkowanie materiałów prasowych przechowywanych w trzech różnych zespołach archiwalnych. Materiały te obejmują przede wszystkim prasę wydawaną w czasie wojny, zarówno konspiracyjną, jak i gadzinową. Występują wśród nich tytuły rzadkie, zachowane fragmentarycznie, niektóre z nich wydawane były przez bardzo krótki okres czasu lub pod identyczną nazwą przez różnych wydawców, co utrudniało rozpoznanie materiałów. Podczas ich identyfikacji posiłkowaliśmy się literaturą dostępną w bibliotece podręcznej Studium oraz internetowymi bazami danych obejmującymi zbiory polskich bibliotek.

W wyniku przeprowadzonych przez nas prac stworzony został jeden zespół archiwalny pod nazwą „Zbiór prasy i materiałów informacyjnych”. Zawarte w nim materiały prasowe zostały uporządkowane w ramach 3 serii: I. Prasa konspiracyjna, gadzinowa i powojenna, II. Materiały prasowe wydzielone z zespołu „Skrzynie”, III. Materiały nieznanego pochodzenia - VARIA. Materiałom nadano układ alfabetyczny w ramach serii, wewnątrz teczek zaprowadzono układ chronologiczny. Jednostki osygnowano sygnaturą ciągłą dla całego zespołu, część z nich została również spaginowana. Przygotowano nową ewidencję w programie MS Excel (częściowo w oparciu o istniejące spisy, częściowo z natury). 
Materiały przechowywane dotychczas w zużytych opakowaniach zostały przepakowane $\mathrm{w}$ teki z tektury bezkwasowej, w trakcie prac oznaczono także jednostki wymagające interwencji konserwatorskiej.

Anna Sokót

Archiwum Narodowe w Krakowie 